\title{
O PRZESŁUCHANIU POKRZYWDZONYCH PRZESTECSTWAMI Z ART. 197-199 K.K. STUDIUM Z ZAKRESU STOSOWANIA PRAWA
}

Streszczenie. Przedmiot podjętych rozważań stanowi problematyka stosowania art. 185c $\S 2$ k.p.k., zgodnie z którym osoby pokrzywdzone przestępstwami z art. 197-199 k.k. przesłuchiwane są w charakterze świadków na posiedzeniu sądowym. Przepis ten wprowadza szczególny tryb przesłuchania świadka pokrzywdzonego przy prowadzeniu postępowań w sprawach o przestępstwa seksualne. Intencją prawodawcy jest zagwarantowanie ofiarom tych przestępstw wyższego standardu ochrony. W wyniku analiz przedstawiono ustalenia poczynione przez Rzecznika Praw Obywatelskich w ramach postępowania mającego określić, w jaki sposób cele prawodawcy są realizowane w praktyce. Zauważono, że niejednokrotnie pomiędzy zawiadomieniem o popełnieniu przestępstwa a przesłuchaniem osoby pokrzywdzonej upływa kilkadziesiąt dni. W następstwie tego intencja prawodawcy nie może zostać zrealizowana. Podjęte analizy zakończone zostały refleksją teoretycznoprawną poświęconą skuteczności przepisów prawa. W konkluzji wskazano, że skuteczność wymaga w szczególności wzięcia pod uwagę relacji zachowań adresatów do założonych przez prawodawcę celów.

Słowa kluczowe: kodeks postępowania karnego, przesłuchanie, ofiara czynności seksualnej, Rzecznik Praw Obywatelskich, skuteczność przepisów prawa.

\section{INTENCJA PRAWODAWCY}

Zgodnie z art. 185c $§ 2$ ustawy z dnia 6 czerwca 1997 r. - Kodeks postępowania karnego (tekst jedn. Dz.U. z 2017 r., poz. 1904 ze zm.; dalej: k.p.k.) w sprawach o przestępstwa określone w art. 197-199 ustawy z dnia 6 czerwca 1997 r. - Kodeks karny (tekst jedn. Dz.U. z 2017 r., poz. 2204 ze zm.; dalej: k.k.) przesłuchanie pokrzywdzonego w charakterze świadka przeprowadza sąd na posiedzeniu, w którym mają prawo wziąć udział prokurator, obrońca oraz pełnomocnik pokrzywdzonego. Na rozprawie głównej odtwarza się sporządzony zapis obrazu

*Uniwersytet Śląski w Katowicach, Wydział Prawa i Administracji, Katedra Teorii i Filozofii Prawa, slawomir.tkacz@us.edu.pl.

$\mathrm{W}$ toku przedstawionych $\mathrm{w}$ ramach $\mathrm{w}$ wystąpienia analiz wykorzystano materiały zebrane w trakcie postępowania wyjaśniającego wszczętego z inicjatywy Rzecznika Praw Obywatelskich w sprawie o sygn. BPK.518.5.2015. Autor jest głównym specjalistą w Biurze Rzecznika Praw Obywatelskich - Biurze Pełnomocnika Terenowego Rzecznika Praw Obywatelskich w Katowicach. Poglądy przedstawione w niniejszym opracowaniu są wynikiem zainteresowań naukowych autora artykułu i nie stanowią one stanowiska Biura Rzecznika Praw Obywatelskich. 
i dźwięku przesłuchania oraz odczytuje się protokół przesłuchania. Przepis ten wprowadza szczególny tryb przesłuchania świadka pokrzywdzonego przy prowadzeniu postępowań w sprawach o przestępstwa określone w art. 197 k.k. (zgwałcenie i wymuszenie czynności seksualnej), art. 198 k.k. (seksualne wykorzystanie niepoczytalności lub bezradności) i art. 199 k.k. (seksualne wykorzystanie zależności). Przytoczony przepis wszedł w życie 27 stycznia 2014 r. zgodnie z ustawą z dnia 13 czerwca 2013 r. o zmianie ustawy - Kodeks karny oraz ustawy - Kodeks postępowania karnego (Dz.U. z 2013 r., poz. 849).

Niezwykle interesujących informacji, zmierzających do ustalenia historycznych intencji ustawodawcy, stojących za wprowadzeniem danego przepisu bądź ustawy, mogą dostarczyć materiały legislacyjne (Bielska-Brodziak 2017, 21-34; Bielska-Brodziak, Tkacz 2018, 163-165). Wykorzystanie ich na gruncie interpretacji pojawia się pod hasłem „historii legislacyjnej”. Historia legislacyjna wykorzystywana jest $\mathrm{w}$ procesie interpretacji w ten sposób, że interpretator sięga po projekty aktów prawnych, ich uzasadnienia, zapisy debat parlamentarnych, czy też inne dokumenty legislacyjne, aby na ich podstawie konstruować, przyjmować bądź odrzucać hipotezy interpretacyjne. Materiały legislacyjne mogą stanowić źródło wiedzy o różnego rodzaju faktach (Tobor 2016, 180). Dla uzyskania informacji o celu, który prawodawca wiązał z wprowadzeniem danej regulacji najczęściej używane są uzasadnienia projektów ustaw, bowiem właśnie one zawierają wyjaśnienie motywów, z jakich prawodawca podejmuje swoją aktywność prawotwórczą.

Analiza Poselskiego projektu ustawy o zmianie ustawy Kodeks karny oraz ustawy - Kodeks postępowania karnego (Poselski projekt 2012; dalej: projekt) w części, która stanowi przedmiot niniejszych rozważań - w uzasadnieniu - pokazuje, że deklarowaną intencją prawodawcy było wprowadzenie maksymalnej ochrony ofiar przestępstw szczególnie destrukcyjnych dla ich integralności psychicznej ${ }^{1}$. W tym celu ustawodawca postanowił ograniczyć do minimum czynności wiążące się z przesłuchaniami ofiar przemocy seksualnej. Wskazano, że pokrzywdzony w toku postępowania karnego, co do zasady, powinien zostać przesłuchany tylko raz - w toku postępowania przygotowawczego, na posiedzeniu prowadzonym przez sąd (tamże). Projektodawca exspressis verbis wyraził pogląd, że

opowiadanie o doznanej przemocy seksualnej wiąże się z ponownym przeżywaniem emocji, które towarzyszyły zdarzeniu. Dlatego ofiary zgwałceń są w sposób szczególny narażone na tzw. wtórną wiktymizację, czyli ponowne skrzywdzenie m.in. przez niewłaściwą reakcję otoczenia na to, co je spotkało. Także z tych powodów wymagają szczególnej ochrony (tamże).

Zauważyć trzeba, że pierwotnie rozwiązanie przewidziane w art. 185c $\S 2$ k.p.k. miało dotyczyć wyłącznie przestępstw określonych w art. 197 k.k.

${ }^{1}$ Wszystkie powołane w toku dalszych rozważań materiały legislacyjne cytuję za: www.sejm. gov.pl (zakładka: Prace Sejmu VII Kadencji. Proces legislacyjny. Przebieg procesu legislacyjnego. Druk nr 998) [dostęp 21.11.2017]. 
(tamże). Zwrócił na to uwagę m.in. w przedłożonej opinii do projektu Sąd Najwyższy, który podniósł, że przemyślenia wymaga sens zawężania proponowanego wyjątkowego trybu przesłuchania pokrzywdzonego w charakterze świadka jedynie do przestępstwa zgwałcenia (Sąd Najwyższy 2013). Wskazano, że: „Te same względy, które decydują o zminimalizowaniu dolegliwości związanych z przesłuchaniem w tego rodzaju sprawach, przesądzają o potrzebnie [sic!] uprzywilejowania pokrzywdzonego przestępstwem z art. 198 k.k. lub art. 199 k.k." (tamże). W toku dalszych prac legislacyjnych tryb określony w art. 185c $§ 2$ k.p.k. postanowiono odnieść także do art. 198 k.k. oraz 199 k.k. (Sprawozdanie Komisji 2013).

Opinie zebrane w toku procesu legislacyjnego pozwalają stwierdzić, że proponowane zmiany zyskały aprobatę zarówno ekspertów (Sakowicz 2013), jak również Krajowej Rady Sądownictwa (Opinia Krajowej Rady Sądownictwa 2013) i Sądu Najwyższego (Sąd Najwyższy 2013). Monika Płatek, uznając proponowane zmiany co do istoty za zasadne, wskazywała jednakże, że przepis ten nie miałby racji bytu

w warunkach, w których zakłada się profesjonalizm wolny od seksizmu policji, lekarzy, psychologów, prokuratorów i sędziów. [...] Tworzenie przepisów szczegółowych dla art. 197 k.k. stanowi przyznanie, iż ściganie tego przestępstwa jest utrudnione seksizmem, jakim przesiąknięte są praktyki organów ściągania [sic!]. Stosowne w tej sytuacji jest raczej rugowanie seksizmu z całego wymiaru sprawiedliwości, niż ograniczanie praktyki rugowania seksizmu wyłącznie do art. 197 k.k. (Płatek 2013).

W toku procesu legislacyjnego zaproponowane rozwiązanie dotyczące trybu przesłuchania w charakterze świadków pokrzywdzonych przestępstwami, określonymi w art. 197-199 k.k., nie wywołały kontrowersji. Sejm VII kadencji na 39. posiedzeniu w dniu 10 maja 2013 r. uchwalił ustawę 444 głosami „,za”, przy braku głosów „przeciw”, jeden poseł wstrzymał się od głosu (Poselski projekt. III czytanie 2013). Poprawki Senatu w części przyjęte przez Sejm nie odnosiły się do istoty wprowadzonych przepisów (tamże).

W doktrynie wprowadzenie nowych regulacji, określających zasady przesłuchania pokrzywdzonych przestępstwami z art. 197-199 k.k., przyjęto z uznaniem. Wskazywano, że rozwiązania nakładają na organy przeprowadzające czynności procesowe w sprawach o takim charakterze obowiązek takiego ich wykonywania, by ograniczyć do minimum wtórną wiktymizację (Grajewski 2018). Podkreślano, że kierunek wprowadzonych zmian zmierza do tego, aby „osobom dotkniętym szczególnie drastycznymi przestępstwami, jakimi są bez wątpienia przestępstwa seksualne, zagwarantować wyższy standard ochrony w odniesieniu do przesłuchiwania, zasługuje na całkowite poparcie" (Bieńkowska 2013, 30). Podnoszono także, że wskazane rozwiązania realizują standardy wynikające z orzecznictwa Europejskiego Trybunału Praw Człowieka, który podkreślał, iż postępowania karne dotyczące tego rodzaju przestępstw, ze względu na ich szczególne cechy, wymagają ochrony świadków (Orłowska-Zielińska, Szczechowicz 2014, 246). 
W zgodnej opinii komentatorów treść art. 185c § 2 k.p.k. nie rodzi kontrowersji w świetle zasady rzetelnego procesu, a zaproponowany szczególny tryb przesłuchania to standard, który powinien realizować prawodawca wobec innych osób, stanowiących grupę ofiar przestępstw o szczególnych potrzebach w zakresie ochrony (Bieńkowska 2013, 30).

\section{PRAKTYKA}

Rzecznik Praw Obywatelskich, realizując konstytucyjne zadania, podjął z własnej inicjatywy na podstawie art. 9 pkt 3 ustawy z dnia 15 lipca 1987 r. o Rzeczniku Praw Obywatelskich (tekst jedn. Dz.U. z 2017 r., poz. 958) czynności mające na celu ustalenie, w jaki sposób artykuł art. 185c $\S 2$ k.p.k. stosowany jest w praktyce. Podjęcie przez Rzecznika działań z własnej inicjatywy następuje w szczególności wtedy, gdy kierowane do niego sygnały o naruszeniu praw lub wolności nie mogą zostać uznane za wniosek w rozumieniu ustawy (Trociuk 2014, 35).

W toku wszczętego postępowania wyjaśniającego, sygn. akt BPK.518.5.2015, przeprowadzonego przez Biuro Pełnomocnika Terenowego Rzecznika Praw Obywatelskich w Katowicach, Prokuratura Krajowa przedstawiła na prośbę Rzecznika informacje dotyczące okresów, które w praktyce upływają pomiędzy skierowaniem przez prokuraturę do sądu wniosku o przesłuchanie w charakterze świadka pokrzywdzonego w trybie art. $185 \mathrm{c} \S 2$ k.p.k. a przeprowadzeniem przesłuchania na posiedzeniu sądowym. Zebrane z lat 2014-2015 dane dotyczyły wszystkich prokuratur regionalnych w Polsce. Analiza przedłożonych informacji prowadzi do interesujących wniosków ${ }^{2}$. W szczególności należy zwrócić uwagę na znaczące różnice, które występują $\mathrm{w}$ toku postępowań zarówno w ramach poszczególnych jednostek organizacyjnych prokuratury, jak i pomiędzy prokuraturami. Przeprowadzone analizy pozwoliły na wyodrębnienie trzech grup spraw:

a) Ogólną regułą było to, że sądy przeprowadzały przesłuchania osób pokrzywdzonych w charakterze świadka w terminie do dwóch tygodni, ewentualnie do jednego miesiąca od dnia skierowania przez prokuratora wniosku o przeprowadzenie czynności procesowej. Takie terminy w praktyce miały miejsce w przeważającej liczbie spraw.

b) W niektórych jednostkach organizacyjnych prokuratur terminy przesłuchań przez sąd w charakterze świadka pokrzywdzonych przestępstwami o charakterze seksualnym były bardzo krótkie. $Z$ reguły pomiędzy odebraniem zawiadomienia o popełnieniu przestępstwa a przesłuchaniem pokrzywdzonego w charakterze świadka na posiedzeniu sądowym mijał jeden dzień. Było to wynikiem uzgodnionej z sędziami praktyki, polegającej na tym, że przesłuchanie jest

\footnotetext{
${ }^{2} \mathrm{~W}$ toku prowadzonych analiz dokonano badań materiałów zebranych przez Rzecznika Praw Obywatelskich w toku postępowania o sygn. BPK.518.5.2015.
} 
przeprowadzane przez sędziego wyznaczonego w charakterze dyżurnego w konkretnym dniu, który przeprowadza czynność niezwłocznie po złożeniu przez prokuratora prowadzącego postępowanie przygotowawcze stosownego wniosku. Ewentualne przedłużenie terminu było najczęściej wynikiem okoliczności niezależnych od organów wymiaru sprawiedliwości (np. brak możliwości wzięcia udziału w przesłuchaniu przez biegłego psychologa).

c) Niejednokrotnie w praktyce okres, który mijał pomiędzy złożeniem przez prokuraturę wniosku o przesłuchanie na posiedzeniu sądowym w charakterze świadka osoby pokrzywdzonej przestępstwem z art. 197-199 k.k. a przeprowadzeniem czynności przekraczał 50 dni, a w skrajnych sytuacjach nawet trzy miesiące. Stanowiło to następstwo różnych przyczyn. Niektóre z nich były zależne od pokrzywdzonych (czterokrotne niestawiennictwo pokrzywdzonej w sądzie, brak możliwości przesłuchania w pierwotnie wyznaczonym terminie z uwagi na stan nietrzeźwości pokrzywdzonej etc.). Do innych zidentyfikowanych przyczyn, które wpłynęły na przedłużenie terminów można zaliczyć także: odległe terminy wskazane przez biegłych psychologów, alarmy bombowe, brak możliwości technicznych z uwagi na remonty w budynku sądu, urlopy oraz choroby sędziów. Jak wskazywały prokuratury w treści złożonych informacji, prokuratorzy w konkretnych sprawach zwracali się do sądów z prośbą o wyznaczenie wcześniejszego terminu przesłuchania świadka (prośby nie uwzględniono), zgłaszali przewodniczącemu wydziału oraz sędziemu wyznaczonemu do przeprowadzenia czynności konieczność przeprowadzenia ich w możliwie najkrótszym terminie, kierowali do sądów monity i pisma, wnosząc o podjęcie zdecydowanych działań o charakterze dyscyplinującym i organizacyjnym, mających na celu niezwłoczne rozpoznanie wniosków prokuratorów.

W następstwie przeprowadzonych badań Rzecznik Praw Obywatelskich skierował na ręce Ministra Sprawiedliwości wystąpienie generalne, podnosząc problem okresu, który w praktyce mija od momentu złożenia przez pokrzywdzonych zawiadomień o popełnieniu przestępstwa określonego art. 197-199 k.k. do momentu przeprowadzenia przesłuchań przez sądy. W treści wystąpienia Rzecznik zwrócił uwagę na to, że art. 185c $§ 2$ k.p.k. jest wyrazem dbałości o stan psychiczny świadka pokrzywdzonego. Czynność procesowa przesłuchania w charakterze świadka pokrzywdzonego przestępstwami określonymi w art. 197-199 k.k., która ma dostarczyć organowi procesowemu wszystkich informacji dotyczących okoliczności czynu i sprawcy, powinna być przeprowadzona w taki sposób, by ograniczyć do minimum wtórną wiktymizację. Podkreślono, że: „Ta słuszna intencja prawodawcy może zostać zrealizowana jedynie wówczas, gdy przesłuchanie pokrzywdzonego w charakterze świadka przez sąd nastąpi niezwłocznie po złożeniu przezeń zawiadomienia o popełnieniu przestępstwa" (Wystąpienie 2016, sygn. akt BPK.518.5.2015)3. Z uwagi na to Rzecznik wskazał, że rozpatrzenie wniosków

\footnotetext{
${ }^{3}$ Wyszukiwarka wystąpień generalnych RPO: http://www.sprawy-generalne.brpo.gov.pl.
} 
o przesłuchanie pokrzywdzonych w trybie art. 185c $\S 2$ k.p.k. nie może odbywać się w ramach kolejności spraw oczekujących na rozpoznanie w referacie sędziego. W konkluzji wystąpienia Rzecznik Praw Obywatelskich, działając w trybie art. 16 ust. 1 ustawy o Rzeczniku Praw Obywatelskich (tekst jedn. Dz.U. z 2017 r., poz. 958$)^{4}$, zwrócił się do Ministra Sprawiedliwości o rozważenie podjęcia działań, które zapewnią skuteczną ochroną wolności i praw osób pokrzywdzonych przestępstwami określonymi w art. 197-199 k.k. w zakresie okresu oczekiwania przez te osoby na przesłuchanie przez sądy na posiedzeniu w charakterze świadka.

Pismem z dnia 4 sierpnia 2017 r. Ministerstwo Sprawiedliwości poinformowało Rzecznika Praw Obywatelskich, że w Departamencie Legislacyjnym podjęto prace nad zmianami w zakresie postępowania karnego, w ramach których planowane jest wprowadzenie na poziomie ustawowym przepisu, obligującego sądy do przesłuchania pokrzywdzonych przestępstwami z art. 197-199 k.k., nie później niż w terminie 14 dni od daty wpłynięcia wniosku (Pismo Miniserstwa Sprawiedliwości 2017, sygn. akt DL III 072-48/16 w aktach BPK.518.5.2015). Do dnia zakończenia prac nad niniejszym tekstem zapowiedziana przez Ministerstwo Sprawiedliwości nowelizacja nie weszła w życie ${ }^{5}$.

Wydaje się, że de lege ferenda sformułować należy postulat wprowadzenia do kodeksu postępowania karnego zmian, idących w kierunku sygnalizowanym w piśmie Ministerstwa Sprawiedliwości do Rzecznika Praw Obywatelskich.

\section{ZAKOŃCZENIE: KILKA UWAG O SKUTECZNOŚCI PRZEPISÓW PRAWA}

Przedstawione jedno studium z zakresu stosowania prawa pozwala na sformułowanie uwag o charakterze teoretycznoprawnym, odnoszącym się do problematyki skuteczności przepisów prawa. Podkreślić należy, że, jak wskazuje się w literaturze, formułowanie wypowiedzi o skuteczności bądź nieskuteczności działania przepisów prawa wymaga wzięcia pod uwagę nie tylko tego, czy przepisy są stosowane, ale także tego, jak przedstawia się relacja zachowań adresatów do założonych przez prawodawcę celów (Nowacki 2003, 511-539). Przykładowo Jerzy Wróblewski wyodrębnia trzy znaczenia skuteczności przepisów, które nie wykluczają się, a mianowicie: „skuteczność formalną”, polegającą na tym, że adresaci przepisów stosują normy (bez względu na kierujące nimi motywy); ,skuteczność aksjologiczną", której wyrazem jest to, że wartości, które prawodawca uznał za godne ochrony, polegają internalizacji przez adresatów norm oraz „skuteczność

${ }^{4}$ Art. 16 ust. 1 ustawy z dnia 15 lipca 1987 r. o Rzeczniku Praw Obywatelskich (tekst jedn. Dz.U. z 2017 r., poz. 958) stanowi: „W związku z rozpatrywanymi sprawami Rzecznik może przedstawiać właściwym organom, organizacjom i instytucjom oceny i wnioski zmierzające do zapewnienia skutecznej ochrony wolności i praw człowieka i obywatela i usprawnienia trybu załatwiania ich spraw".

${ }^{5} 31$ marca $2018 \mathrm{r}$. 
materialną", która jest osiągana, gdy cele, które określi prawodawca, wprowadzając do systemu prawa określone normy, są istotnie osiągane (Wróblewski 1980, 8). Nie budzi wątpliwości to, że art. 185c $\S 2$ k.p.k. w praktyce jest stosowany, bowiem przesłuchania w charakterze świadków osób pokrzywdzonych przestępstwami określonymi w art. 197-199 k.k. są przeprowadzane przez sądy na posiedzeniach. Wprowadzone zatem przez prawodawcę przepisy są skuteczne w kategoriach skuteczności formalnej. $\mathrm{Z}$ uwagi na zidentyfikowaną w podpunkcie c) praktykę trzeba jednakże zadać pytanie, czy sposób, w jaki art. 185c § 2 k.p.k. jest realizowany przez sądy w tych sprawach, w których pomiędzy skierowaniem przez prokuraturę wniosku o przesłuchanie $\mathrm{w}$ charakterze świadka pokrzywdzonego a przeprowadzeniem przesłuchania na posiedzeniu sądowym upływa czas powyżej jednego miesiąca, urzeczywistnia cel założony przez prawodawcę w postaci ograniczenia do minimum wtórnej wiktymizacji.

Wyraźnie wskazuję, że z uwagi na to, iż adresatem art. 185c $§ 2$ k.p.k. są organy państwa, przyjąć należy, że posiadają one wiedzę zarówno o treści wskazanego przepisu, jak i wartościach uznawanych przez prawodawcę oraz celach, które winny być realizowane $\mathrm{w}$ procesie stosowania prawa $-\mathrm{w}$ tym określonych w materiałach legislacyjnych oraz zidentyfikowanych w poglądach doktryny (Gryniuk 1979, 22-25).

Jerzy Wróblewski podkreślił, że sądowe stosowanie prawa może być przedmiotem oceny zewnętrznej, dokonywanej z punktu widzenia wartości, które traktuje się jako kryteria niezależne od tego, czy i w jakim zakresie nakłada je prawo obowiązujące (Wróblewski 1988, 83). Kryteria takich ocen mogą stanowić w szczególności rozmaite względy o charakterze moralnym oraz instrumentalnym (tamże). Autor expressis verbis pisał, że „Oceny instrumentalne sądowego stosowania prawa wyrażają wartościowanie ze względu na stopień realizacji założonych celów (skuteczność stosowania prawa) oraz ze względu na stopień osiągania tego celu (operatywność stosowania prawa)" (tamże, 84).

W piśmiennictwie wskazuje się, że w każdym przypadku ustalenia celu przepisu, niezależnie od podawanej argumentacji, jest on celem widzianym oczyma tego, kto go ustala (Nowacki 2003, 523). Przedstawiona w pierwszej części studium analiza materiałów powstałych w toku procesu legislacyjnego, którego efektem było wejście w życie art. 185c § 2 k.p.k., w moim przekonaniu (w ocenie zewnętrznego obserwatora) pozwala na stwierdzenie, że intencją prawodawcy było zminimalizowanie dolegliwości związanych z przesłuchaniem ofiar przestępstw o charakterze seksualnym. Dokonując oceny zewnętrznej praktyki opisanej w punkcie 2, sytuacje, w których pomiędzy złożeniem przez prokuratura wniosku o przesłuchanie na posiedzeniu sądowym w charakterze świadka osoby pokrzywdzonej przestępstwem seksualnym a przeprowadzeniem tej czynności przez sąd mija ponad jeden miesiąc, należy ocenić negatywnie. Nie mam wątpliwości, że w tych przypadkach trudno postanowienia art. 185c § 2 k.p.k. uznać za skuteczne w kategoriach skuteczności materialnej. Nieco trudniej jest dokonać 
kwalifikacji postanowień wskazanego przepisu w kategoriach skuteczności aksjologicznej. Wymaga to bowiem spojrzenia na omawianą praktykę w kategoriach przyczyn i skutków. Wydaje się, że przyczynami zaobserwowanej sytuacji są przede wszystkim: brak wystarczającej komunikacji na linii prokuratura - sądy, problemy organizacyjne w pracy sądów (sędziów) oraz rozmaite problemy o charakterze technicznym. Być może jest i tak, że wobec obciążenia, wynikającego z konieczności prowadzenia postępowań sądowych i wydawania orzeczeń kończących owe postępowania, sędziowie nie przykładają należytej wagi do czynności pierwszego przesłuchania pokrzywdzonego w charakterze świadka w sprawach przestępstw o charakterze seksualnym. Nic nie wskazuje jednakże na to, aby sędziowie nie uznawali narzuconych przez prawodawcę wartości, odnoszących się do konieczności zapewnienia szczególnej ochrony ofiarom przestępstw o charakterze seksualnym. Jeśli tak jest $\mathrm{w}$ istocie, w mojej ocenie wskazane przyczyny zaistniałego stanu rzeczy można wyeliminować, nawet bez dokonania zmian w ustawodawstwie.

Mówiąc o negatywnych skutkach odległych terminów przesłuchań w charakterze świadków pokrzywdzonych przestępstwami określonymi w art. 197199 k.k., oprócz uprzednio wskazywanego zagadnienia związanego z realizacją $\mathrm{w}$ procesie stosowania prawa intencji prawodawcy, aby ofiarom przestępstw seksualnych zagwarantować szczególną ochroną, podnieść należy problem braku efektywności przesłuchań pokrzywdzonych w charakterze świadków w dużym odstępie czasowym od zaistniałego czynu przestępczego (nie można także pominąć aspektu ewentualnego wpływania innych osób na pokrzywdzonych w tym okresie). Trzeba także pamiętać o kwestii braku efektywności postępowań przygotowawczych w okresie od złożenia zawiadomienia o popełnieniu przestępstwa do pierwszego przesłuchania pokrzywdzonego w charakterze świadka, w tym w aspekcie konieczności koncentracji czynności procesowych. Na marginesie można zauważyć, że zgodnie z art. 310 § 1 k.p.k. regułą ogólną jest to, iż śledztwo powinno być ukończone w ciągu trzech miesięcy - informacje przedstawione w punkcie 2 dowodzą, że zdarzały się i takie przypadki, w których pierwsze przesłuchanie pokrzywdzonego w toku postępowania miało miejsce już po upływie tego terminu. Nie budzi wątpliwości to, że wskazane negatywne skutki mogą godzić w ogólniejszy cel przepisów procesu karnego, jakim jest zaufanie pokrzywdzonych do organów wymiaru sprawiedliwości.

Siłą rzeczy dokonane ustalenia odnoszą się do skuteczności samych działań prawodawczych, skoro bowiem cele prawodawcy nie są realizowane przez organy stosujące prawo, trudno mówić o skuteczności wytworów działalności prawodawczej. Z całą pewnością jest to niezadawalający stan rzeczy, gdyż albo jest tak, że organy stosujące prawo winny realizować cele prawodawcy, albo godzimy się na to, że cele te nie będą w istocie osiągane. Niewątpliwie to ostatnie zagadnienie winno być przedmiotem zainteresowania odrębnego opracowania. 


\section{BIBLIOGRAFIA}

Bielska-Brodziak, Agnieszka. 2017. „Po co prawnikom materiały legislacyjne”. Radca.pl. 3:21-34. https:// oirp.katowice.pl/add/vrecord/1402630714/1403118239/1402630728_0.pdf [dostęp 21.11.2017].

Bielska-Brodziak, Agnieszka, Sławomir Tkacz. 2018. „Legislative Materials as the Legislator's Voice in the Discourse on Legal Principles". Annales Universitatis Mariae Curie-Skłodowska. Sectio G. Ius 65 (1): 155-171.

Bieńkowska, Ewa. 2014. „Pokrzywdzony w świetle najnowszych nowelizacji przepisów kodeksu karnego". Prokuratura i Prawo 3: 16-31.

Grajewski, Jan. 2018. Komentarz aktualizowany do art.185(c) Kodeksu postepowania karnego. Warszawa: Wolters Kluwer Business [źródło elektroniczne: Lex Omega, dostęp 21.11.2017].

Gryniuk, Anna. 1979. Świadomość prawna. (Studium teoretyczne). Toruń: Uniwersytet Mikołaja Kopernika.

Nowacki, Józef. 2003. Studia z teorii prawa. Kraków: Kantor Wydawniczy Zakamycze.

Orłowska-Zielińska, Bogna, Krystyna Szczechowicz. 2014. „Ograniczenia zasady bezpośredniości w polskim procesie karnym”. Studia Warmińskie 51: 239-255.

Tobor, Zygmunt. 2016. „Rola materiałów legislacyjnych w porządku prawnym”. Przegląd Prawa i Administracji 104 - Systemowość prawa: 171-181.

Trociuk, Stanisław. 2014. Komentarz do ustawy o Rzeczniku Praw Obywatelskich. Warszawa: Biuro Rzecznika Praw Obywatelskich.

Wróblewski, Jerzy. 1980. „Skuteczność prawa i problemy jego badania”. Studia Prawnicze 1-2: $3-26$.

Wróblewski, Jerzy. 1988. Sądowe stosowanie prawa. Warszawa: Państwowe Wydawnictwo Naukowe.

\section{Akty prawne}

Ustawa z dnia 13 czerwca 2013 r. o zmianie ustawy - Kodeks karny oraz ustawy - Kodeks postępowania karnego (Dz.U. z 2013 r., poz. 849).

Ustawa z dnia 15 lipca 1987 r. o Rzeczniku Praw Obywatelskich (tekst jedn. Dz.U. z 2017 r., poz. 958).

Ustawa z dnia 6 czerwca 1997 r. - Kodeks karny (tekst jedn. Dz.U. z 2017 r., poz. 2204 ze zm.).

Ustawa z dnia 6 czerwca 1997 r. - Kodeks postępowania karnego (tekst jedn. Dz.U. z 2017 r., poz. 1904 ze zm.).

\section{Materiały legislacyjne}

Opinia Krajowej Rady Sądownictwa z dnia 10 stycznia 2013 r. w przedmiocie projektu o zmianie ustawy - Kodeks karny oraz ustawy - Kodeks postępowania karnego. 4.02.2013. http://orka. sejm.gov.p1/Druki7ka.nsf/0/1B0C4952EFB99FE5C1257B110042013E/\%24File/998-004.pdf [dostęp 21.11.2017].

Pismo Ministerstwa Sprawiedliwości z dnia 4 sierpnia 2017 r., sygn. akt DL III 072-48/16 w aktach BPK.518.5.2015. https://www.rpo.gov.pl/sites/default/files/Przes $\%$ C5\%82uchania $\% 20$ ofiar\%20gwa\%C5\%82t\%C3\%B3w\%20-\%20odpowied\%C5\%BA\%20MS\%204.08.2017.pdf [dostęp 21.11.2017].

Płatek Monika. Opinia na temat projektowanych zmian art. 185a, 185b oraz 185c kpk. Zawartych w poselskim projekcie ustawy o zmianie ustawy - Kodeks karny oraz ustawy - Kodeks postępowania karnego (druk nr 998). 4.03.2013. http://orka.sejm.gov.pl/rexdomk7.nsf/ Opdodr?OpenPage\&nr=998 [dostęp 21.11.2017]. 
Poselski projekt ustawy o zmianie ustawy - Kodeks karny oraz ustawy - Kodeks postępowania karnego. 22.11.2012. Druk nr 998. http://orka.sejm.gov.pl/Druki7ka.nsf/0/EC596B237378B3 FCC1257AD7002C05FC/\%24File/998.pdf [dostęp 21.11.2017].

Poselski projekt ustawy o zmianie ustawy - Kodeks karny oraz ustawy - Kodeks postępowania karnego. Druk nr 998. III czytanie na posiedzeniu Sejmu. 10.05.2013. http://www.sejm.gov.pl/Sejm7. nsf/PrzebiegProc.xsp?id=5316FA861F16A36AC1257AD8002D77A0 [dostęp 21.11.2017].

Sakowicz Andrzej. Opinia prawna na temat projektu ustawy o zmianie ustawy - Kodeks karny oraz ustawy - Kodeks postępowania karnego (druk nr 998). 4.02.2013. http://orka.sejm.gov. pl/rexdomk7.nsf/Opdodr?OpenPage\&nr=998 [dostęp 21.11.2017].

Sąd Najwyższy. Opinia do poselskiego projektu ustawy o zmianie ustawy - Kodeks karny oraz ustawy - Kodeks postępowania karnego. 24.01.2013. http://orka.sejm.gov.pl/Druki7ka.nsf/0/1E7 B0DFE39EAFB01C1257B080045116A/\%24File/998-003.pdf [dostęp 21.11.2017].

Sprawozdanie Komisji Nadzwyczajnej do spraw zmian w kodyfikacjach o poselskim projekcie ustawy o zmianie ustawy - Kodeks karny oraz ustawy - Kodeks postępowania karnego, poselskim projekcie ustawy o zmianie ustawy - Kodeks karny oraz poselskim projekcie ustawy o zmianie ustawy - Kodeks karny oraz ustawy - Kodeks postępowania karnego. Druk nr 1277. 17.04.2013. http://www.sejm.gov.pl/Sejm7.nsf/druk.xsp?nr=1277 [dostęp 21.11.2017].

Wystąpienie Rzecznika Praw Obywatelskich do Ministra Sprawiedliwości z dnia 8 września 2016 r., sygn. akt BPK.518.5.2015. http://www.sprawy-generalne.brpo.gov.pl/szczegoly.php?pismo=8 34614\&sygnatura=BPK.518.5.2015 [dostęp 21.11.2017].

\title{
Stawomir Tkacz
}

\section{ABOUT QUESTIONING PEOPLE HARMED BY OFFENCES UNDER ART. 197-199 OF THE POLISH PENAL CODE STUDY ON APPLICATION OF LAW}

\begin{abstract}
The subject matter of the considerations is the issue of the application of art. 185c $\S 2$ of the [Polish] penal procedure code, according to which people harmed by offences under art. 197-199 p.c. are interrogated as witnesses at a court session. This provision introduces a special mode of interrogation of a victim witness while conducting proceedings in cases involving sexual offences. The intention of the legislator is to guarantee the victims of these crimes a higher standard of protection. In the course of the conducted analyses, the findings made by the Commissioner for Citizens' Rights in the course of the proceedings were presented, aiming at determining how the legislator's objectives are implemented in practice. It has been noticed that often several dozen days pass between the notification of a crime and the questioning of the victim. As a result, the intention of the legislator cannot be implemented. The undertaken analyses were concluded with a theoretical reflection on the effectiveness of legal provisions. In conclusion, it was pointed out that effectiveness requires, in particular, taking into account the relationship between the behavior of recipients and the goals assumed by the legislator.
\end{abstract}

Keywords: Code of Criminal Procedure, hearing, victim of sexual activity, Ombudsman, effectiveness of legal provisions. 